\title{
THE EFFECTIVENESS OF A REGIONAL RAILWAY LINE - CASE STUDY ON THE TRACK HODONÍN - HOLÍČ NAD MORAVOU
}

\begin{abstract}
The effectiveness of regional railway lines has been a much discussed theme recently mainly in case of lines which are not sufficient per the capacity requirements of carriers, or vice-versa, which are utilised only to a minimum extent. The article deals with the assessment of options how to utilise the railway line Hodonín - Holíc nad Moravou with respect to its inclusion into Revision of Transport Expenses document. Based on the analysis of present operation situation in that border crossing as well as on the analysis of passenger and freight railway transport operation various options of utilising the line have been investigated with respect to operation and economic options of individual alternatives.
\end{abstract}

Keywords: regional railway transport, effectiveness, passenger transport, freight transport, manager of infrastructure

\author{
Adrián Šperka ${ }^{1}$ \\ ${ }^{1}$ Faculty of Operation and Economics of Transport and Communications University of Žilina, \\ Univerzitná 8215/1, 01026 Žilina; +421/41 513 3434; adrian.sperka@fpedas.uniza.sk \\ Anna Dolinayová ${ }^{2}$ \\ ${ }^{2}$ Faculty of Operation and Economics of Transport and Communications University of Žilina, \\ Univerzitná 8215/1, 01026 Žilina; +421/41 513 3434; anna.dolinayova@fpedas.uniza.sk
}

\section{Introduction}

A regional line is of a local importance; it serves for public railway transport and it runs to a national or another regional line. Transport on such a line is usually characterised with a simplified control and operation of motor wagons, or electric units in passenger transport. In freight transport the fraction on regional lines is provided mostly with handling trains.

The issue of sustainability and operation on regional lines is dealt by Dolinayová et al. (Dolinayová et al., 2017). In their article they point out the importance of regional railway transport in context of an economic growth of regions. Regional railway transport has a nonsubstitutable place in regions with a higher standard of living, and in case of providing a quality service it leads to a significant improvement of performances (Masek \& Kendra, 2013). Gašparík et al. investigated the provision of services in regional passenger railway transport and the interaction of a passenger with an order party of the transport service (Gašparík et al., 2015). An ecological aspect of regional railway and road transport is covered by Skrúcaný at al. (Skrúcaný et al., 2016) who studied the environmental burden caused with road and railway regional transport on the basis of simulating the fuel consumption of a bus and a train on Žilina - Rajec line with a certain amount of passengers. Seidenglanz et al. referred to a diversified organisation of regional public transport in three neighbouring Central European countries: the Czech Republic, Austria and Germany (Seidenglanz et al., 2015). Guihéry considered costs structure of operating regional railway passenger transport before and after competition and showed that the introduction of competition in Leipzig region had reduced the level of subsidy by $20 \%$, and improved productivity of the incumbent operator (Guihéry, 2014).

Advantages of regional railway transport mostly include a small negative environmental burden. However, there are also railway lines where performances of railway transport drop from year to year and railway transport is replaced with other modes of transport, mostly the road one.

The railway line Hodonín (CZ) - Holíč nad Moravou (SK) is one of such lines. Passenger transport was stopped here in December 2004 and freight transport was stopped here even at the beginning of the $90 \mathrm{~s}$ in the $20^{\text {th }}$ century, in spite of the electrification $(25 \mathrm{kV} / 50 \mathrm{~Hz})$ which was finished in December 1987. Thus there in the Slovak section this line was listed in Revision of Transport Expenses document, which was prepared by the Ministry of Transport and Construction of the Slovak Republic in order to reduce costs expended on railway lines where railway transport was operated only in small extent or not at all. This document contains more than 25 railway lines in the territory of the Slovak Republic operated by Železnice Slovenskej republiky (ŽSR, in English: Railways of the Slovak Republic).

\section{Methodology}

A railway line creates a transport route for rail vehicles in order to provide railway transport. The railway infrastructure is built, maintained and operated by the government through ŽSR, a manager of the infrastructure (Ministerstvo dopravy a výstavby SR, 2011).

Whether the operation and maintenance of a railway line is effective or not, and to what extent, is observed using indicators anchored in the Contract for the Operation of Railway Infrastructure. It is a contract between the Ministry of Transport and Construction and ŽSR. The current contract has been concluded for the period 2017 2021. Usually it is made for 4 years and it contains rights and duties of both parties, as well as sanctions in case of not fulfilling conditions of the contract. Table 1 lists individual groups of indicators and their corresponding indicators (Železnice Slovenskej republiky, 2016). 
Table 1. Indicators of Contract for the Operation of Railway Infrastructure

\begin{tabular}{|c|c|}
\hline Group of Indicators & Indicator \\
\hline \multirow{6}{*}{ Operation } & Length of lines in $\mathrm{km}$ \\
\hline & Categorisation of lines \\
\hline & $\begin{array}{l}\text { Number of transport points for passenger } \\
\text { and freight transport }\end{array}$ \\
\hline & Throughput of line sections \\
\hline & The highest line speed \\
\hline & $\begin{array}{l}\text { Accidents caused by a manager of } \\
\text { infrastructure by categories }\end{array}$ \\
\hline \multirow{5}{*}{ Performance-related } & Regular scope of train transport \\
\hline & $\begin{array}{l}\text { Utilisation of a forward performance of a } \\
\text { line section }\end{array}$ \\
\hline & $\begin{array}{l}\text { Degree of occupancy of a line section } \\
\text { with regular transport }\end{array}$ \\
\hline & List of carriers \\
\hline & $\begin{array}{l}\text { Number of employees who guarantee the } \\
\text { subject of the Contract for the Operation } \\
\text { of Railway Infrastructure }\end{array}$ \\
\hline \multirow{3}{*}{ Qualitative } & Standards of railway lines and stations \\
\hline & Fulfilling of a line timetable \\
\hline & $\begin{array}{l}\text { Full overviews of deviations from } \\
\text { construction parameters of operated lines }\end{array}$ \\
\hline \multirow{5}{*}{ Economic } & $\begin{array}{l}\text { Summary transport performances of a } \\
\text { minimum access package and line access } \\
\text { to facilities of passenger and freight } \\
\text { transport, as well as to facilities of the } \\
\text { carrier }\end{array}$ \\
\hline & $\begin{array}{l}\text { Proceeds out of the fee for railway } \\
\text { infrastructure within the division into } \\
\text { passenger and freight transport, and the } \\
\text { carrier }\end{array}$ \\
\hline & Cost rate \\
\hline & $\begin{array}{l}\text { Performances expressed in train } \\
\text { kilometres and gross tonne-kilometres }\end{array}$ \\
\hline & $\begin{array}{l}\text { Total real revenues and costs per a line } \\
\text { section }\end{array}$ \\
\hline
\end{tabular}

Individual indicators are observed by a manager of the infrastructure in more detail in the module Controlling within the SAP ECC System. Quarterly a qualitative indicator of a full overview of deviations from construction parameters of operated lines is evaluated. Half-yearly economic indicators of summary transport performances and proceeds out of the fee for railway transport route are evaluated. Other indicators are evaluated annually (Dolinayová \& Nedeliaková, 2015).

To verify a forward performance in chapter 4 we will use the methodology of a theoretical forward performance of ŽSR which is characterised with the following steps (Gašparík \& Šulko, 2016):

- in the first table there are multiples of number of trains $\mathrm{N}_{1}$ and $\mathrm{N}_{2}$ which represent the number of trains,

- in the second table there are times of occupancy of an interstation section with individual sequences of trains,

- total time of occupancy $\mathrm{T}^{\prime}$ obs is calculated as a sum of multiples of a product of the number of trains of a given sequence, and unit time of occupancy of the given sequence, i.e. matching cells of both tables are multiplied,
- value $\mathrm{T}^{\prime}$ obs will be increased in $10 \%$,

- time of occupancy is calculated as a share of increased time of occupancy and the number of trains,

- average time of occupancy $t_{o b s}$ and time of intervals $t_{\text {medz }}$ is determined,

- required time of intervals is found per the regulation ŽSR D 24,

- actual time of intervals will be compared with the required one $t_{\text {medz }}^{\text {pož }} \leq t_{m e d z}^{s k}$

- a prospective practical throughput as well as other qualitative indicators of a line timetable will be calculated.

The rate of occupancy is represented with an indicator of the degree of occupancy $s_{0}$. The degree of occupancy is a ratio of the total time of occupancy $T_{\text {obs }}$ of the investigated operation facility and the total calculation time T (usually 24 hours) which is reduced with the time required for maintenance and repairs $T_{\text {výl }}$ and occupancy of permanent handlings $\mathrm{T}_{\text {stál }}$ (Gašparík \& Šulko, 2016).

$$
S_{o}=\frac{T_{o b s}}{T-\left(T_{v y ́ l}+T_{s t a ́ l}\right)}
$$

A line timetable is considered sufficiently occupied when it shows a degree of occupancy from 0.5 to 0.67 . The degree of occupancy is a dimensionless number (Gašparík \& Šulko, 2016).

\section{Operation-Technical Characteristics of the Line Section Hodonín - Holíč nad Moravou}

After a dissolution of Czechoslovakia on January 1, 1993 and origin of two sovereign states of the Czech Republic and Slovak Republic the originally domestic line became one of the shortest interstate lines connecting two states.

The railway border crossing Hodonín - Holíč nad Moravou comprises (Železnice Slovenskej republiky, 2018):
a) the frontier transitional station Hodonín,
b) the frontier station Holíč nad Moravou,
c) the frontier line.

\subsection{The Frontier Transitional Station Hodonín}

RS Hodonín was made available to public on May 1, 1841. Alongside on that date there was an operation on the line Břeclav - Uherské Hradiště initiated.

In 1999 - 2000 RS Hodonín underwent a complete reconstruction including the modernisation of a station interlocking plant and access for disabled passengers. Currently the interlocking plant is controlled from CDP Přrev. Table 2 contains the number and type of tracks located in RS Hodonín (Pagáč, 2018).

Table 2. The Number and Type of Tracks in RS Hodonín

\begin{tabular}{|l|l|}
\hline $\begin{array}{l}\text { Type of a Station } \\
\text { Track }\end{array}$ & Number \\
\hline
\end{tabular}




\begin{tabular}{|l|l|}
\hline transport & 19 \\
\hline handling & 22 \\
\hline other & 5 \\
\hline
\end{tabular}

There passes the $2^{\text {nd }}$ transit corridor of Správa železničnej dopravnej cesty (SŽDC, in English: Railway Infrastructure Administration) through RS Hodonín. There run 5 active sidings into RS Hodonín.

In RS Hodonín there are the following services available for passengers (České Dráhy, 2018):

- international and domestic ticket office with the option to pay with a card or cash (also in $€$ currency),

- integrated transport system with the option to validate the ticket in a stamping machine,

- bike rental service,

- waiting room,

- toilet for the disabled,

- exchange office operated by the company České Dráhy, a. s. (in English: Czech Railways),

- left-luggage office.

At the same time the RS is equipped with elevators and guide elements for visually handicapped passengers.

RS Hodonín does not provide any equipment (side or front ramp, customs clearance, derrick, etc.) for carriers in freight transport (ČD CARGO, 2017).

\subsection{The Frontier Station Holíč nad Moravou}

Railway station Holíc nad Moravou was made available to public on October 27, 1891. On that date there was also an operation on the line Hodonín - Holíč nad Moravou initiated.

The rail yard and dispatch shed have not undergone a considerable reconstruction. In $\mathrm{RS}$ there is a station interlocking plant of the $1^{\text {st }}$ category activated - group light signals independent on the position of changes with manually reset changes. There in Table 3 is the type and number of tracks in RS Holíc nad Moravou listed (VLAKY.NET, 2004).

Table 3. The Number and Type of Tracks in RS Holíc

\begin{tabular}{|l|l|}
\hline $\begin{array}{l}\text { Type of a Station } \\
\text { Track }\end{array}$ & Number \\
\hline transport & 8 \\
\hline handling & 3 \\
\hline other & 2 \\
\hline
\end{tabular}

Through RS Holíč nad Moravou there also passes a line joining Kúty and Skalica in Slovakia. In RS Holíč nad Moravou there between the last and the first train in the line timetable a traffic closure of the transport service is introduced; its duration always changes to the date when the line timetable comes into force.

Passengers can wait in a waiting room, however, in the RS there is no ticket office. Tickets can be purchased via the Internet or another alternative selling channel, or at a conductor on the train (Železničná spoločnost' Slovensko, 2016).

In freight transport there is a side ramp available to carriers; it is located on the track No. 4 and its surface area is $170 \mathrm{~m}^{2}$. The station is not occupied by an employee of the carrier since handing of shipments in and out is performed during the stay of a handling train (Železničná spoločnost' Cargo Slovakia, 2018).

\subsection{The Frontier Line}

The interstation section Hodonín - Holíč nad Moravou is a single-track section and it is electrified with an alternate traction supply substation $25 \mathrm{kV} / 50 \mathrm{~Hz}$ (Železnice Slovenskej republiky, 2018). The electric operation began on December 3, 1987. Currently it is used only in case of a route deviation within passenger and freight transport, which happens only to a minimum extent (Tomančák, 2000). Table 4 lists a characteristics of the interstation section as it is introduced by Local convention for carriers in the given border crossing (Železnice Slovenskej republiky, 2018).

Table 4. The Characteristics of the Interstation Section

\begin{tabular}{|c|c|}
\hline Position of the state border & $\mathrm{km} 3.009$ \\
\hline $\begin{array}{l}\text { Distance from axes of dispatch } \\
\text { sheds of neighbouring RSs }\end{array}$ & $6.543 \mathrm{~km}$ \\
\hline \multirow{2}{*}{ Boundary of the frontier line } & $\begin{array}{l}\text { RS Hodonín - entry signal HS } \\
\text { on km } 0.990\end{array}$ \\
\hline & $\begin{array}{l}\text { RS Holíč nad Moravou - entry } \\
\text { signal HS on km } 5.900\end{array}$ \\
\hline Stops on the line & Hodonín stop on km 2.100 \\
\hline $\begin{array}{l}\text { The highest permissible line } \\
\text { speed }\end{array}$ & $60 \mathrm{~km} \cdot \mathrm{h}^{-1}$ \\
\hline Braking distance & $400 \mathrm{~m}$ \\
\hline $\begin{array}{l}\text { The biggest length of the train } \\
\text { including a railway tractive } \\
\text { vehicle }\end{array}$ & $665 \mathrm{~m}$ \\
\hline \multirow{2}{*}{$\begin{array}{l}\text { The biggest admissible weight } \\
\text { on axle }\end{array}$} & 22.5 t (Hodonín - km 2.920) \\
\hline & 20.5 t (km 2.920 - Holíč $)$ \\
\hline \multirow{2}{*}{$\begin{array}{l}\text { The biggest admissible weight } \\
\text { on a standard meter of a wagon }\end{array}$} & $8 \mathrm{t} / \mathrm{m}$ (Hodonín - km 2.920) \\
\hline & $7.2 \mathrm{t} / \mathrm{m}(\mathrm{km} 2.920$ - Holíč $)$ \\
\hline \multirow{2}{*}{ Line class } & D 4 (Hodonín - km 2.920) \\
\hline & C $3(\mathrm{~km} 2.920-$ Holíč $)$ \\
\hline Line interlocking plant & $\begin{array}{l}\text { a relay semi-automatic block } \\
\text { with a check of the line } \\
\text { freedom and axle counter }\end{array}$ \\
\hline
\end{tabular}

In the interstation section there is also Hodonín stop located. It is accessible for the disabled, however, in the stop there is no ticket office. The stop is plotted in Fig. 1. 


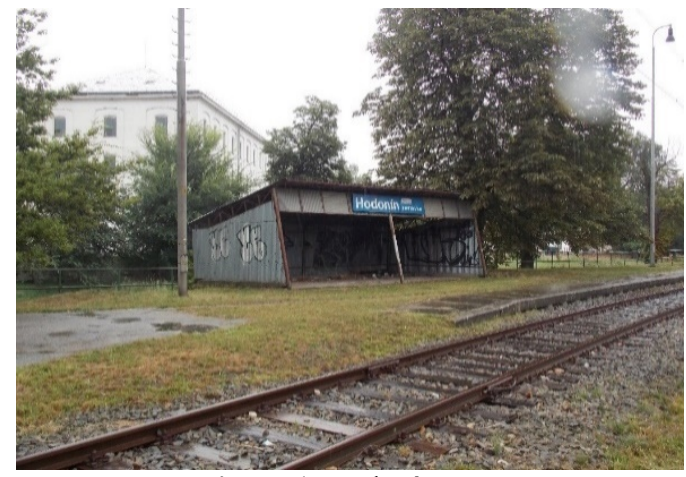

Figure 1. Hodonín Stop

In the interstation section there are 6 bridges in total, out of which 5 are located in the territory of the Slovak Republic. One of bridges is built above Morava river; it connects the Slovak and Czech Republic. This bridge was reconstructed in 2008 (Železnice Slovenskej republiky, 2018).

\section{The Analysis of the Current State of Railway Transport on the line Hodonín - Holíč nad Moravou}

Despite a relatively high provision of train drive and electrification this line is utilised less and less from year to year.

The number of connections of passenger transport trains has been relatively stable during its operation, influenced only with historic events (World War II.). Table 5 contains numbers of individual trains in different periods of operation since 1938 up to 2004 when the operation of passenger transport was stopped (VLAKY.NET, 2017).

Table 5. The Number of Passenger Transport Trains During a Week

\begin{tabular}{|l|l|l|}
\hline $\begin{array}{l}\text { Line } \\
\text { Timetable }\end{array}$ & $\begin{array}{l}\text { Holíč nad Moravou - } \\
\text { Hodonín }\end{array}$ & $\begin{array}{l}\text { Hodonín - } \\
\text { Holíc nad Moravou }\end{array}$ \\
\hline $1938 / 1939$ & 7 & 7 \\
\hline $1941 / 1942$ & 3 & 3 \\
\hline $1947 / 1948$ & 10 & 10 \\
\hline $1950 / 1951$ & 10 & 10 \\
\hline $1958 / 1959$ & 14 & 13 \\
\hline $1968 / 1969$ & 13 & 12 \\
\hline $1976 / 1977$ & 12 & 12 \\
\hline $1979 / 1980$ & 12 & 12 \\
\hline $1982 / 1983$ & 13 & 13 \\
\hline $1988 / 1989$ & 12 & 12 \\
\hline $1989 / 1990$ & 12 & 12 \\
\hline $1991 / 1992$ & 12 & 12 \\
\hline $1994 / 1995$ & 12 & 12 \\
\hline $1995 / 1996$ & 10 & 10 \\
\hline $1996 / 1997$ & 9 & 9 \\
\hline $1998 / 1999$ & 5 & 5 \\
\hline $2002 / 2003$ & 4 & 4 \\
\hline $2003 / 2004$ & 4 & 4 \\
\hline & & \\
\hline & & \\
\hline
\end{tabular}

The number of trains mostly achieved 10 trains in both ways. Most of trains were driving on the line within the line timetable 1958/1959, when there in the way Holíc nad Moravou - Hodonín almost 14 trains were driving on weekdays. A sharp decrease happened within the line timetable 1941/1942, when the operation on the line was affected by the World War II. Since the $90 \mathrm{~s}$ in the $20^{\text {th }}$ century the number of connections was gradually falling down

On September 28, 1997, i.e. when the $1^{\text {st }}$ change of the line timetable $1997 / 1998$ occurred, the operation of passenger transport was stopped at the weekends and on holidays. This operation was provided by bus transport. Since the line timetable 1998/1999 there were only 5 trains driving on the line in both ways, and in the line timetable $2003 / 2004$ the number was reduced to 4 trains only. On December 10, 2004 the operation of passenger transport was completely stopped on the line. Performances of passenger railway transport were taken over by bus transport (VLAKY.NET, 2017).

With respect to limiting elements described in the previous part the freight transport has never been too intensive. It was the electric operation which should have provided the deviation fraction of freight trains out of RS Břeclav, which was significantly overloaded already in the late 80s. In 1991 the operation of freight transport was stopped; even that minimum number of freight trains was returned back to their original route via $\mathrm{RS}$ Břeclav (Tomančák, 2000).

A low utilisation of this line is proved with statistic data obtained from the directorate of ŽSR from 2011 to 2018 introduced in Table 6.

Table 6. A Summary Comparison of Performances of Railway Transport

\begin{tabular}{|l|l|l|l|l|}
\hline $\begin{array}{l}\text { Line } \\
\text { Timetable }\end{array}$ & $\begin{array}{l}\text { Num } \\
\text { ber }\end{array}$ & $\begin{array}{l}\text { Train- } \\
\text { Kilometre }\end{array}$ & $\begin{array}{l}\text { Gross } \\
\text { Tonne- } \\
\text { Kilometre }\end{array}$ & Revenues \\
\hline $2010 / 2011$ & 724 & $2,178.516$ & $73,837.851$ & $2,048.55 €$ \\
\hline $2011 / 2012$ & 726 & $2,184.534$ & $91,771.491$ & $1,990.42 €$ \\
\hline $2012 / 2013$ & 681 & $2,049.129$ & $85,657.203$ & $1,921.02 €$ \\
\hline $2013 / 2014$ & 2 & 6.018 & 433.296 & $6,-€$ \\
\hline $2014 / 2015$ & 1 & 3.009 & 147.441 & $3.37 €$ \\
\hline $2015 / 2016$ & 2 & 6.018 & 433.296 & $6,-€$ \\
\hline $2016 / 2017$ & 0 & 0 & 0 & $0,-€$ \\
\hline $2017 / 2018$ & 0 & 0 & 0 & $0,-€$ \\
\hline
\end{tabular}

Since the $1^{\text {st }}$ change of the line timetable 2010/2011, i.e. March 6, 2011, there in the railway depot Hodonín armament of engine units, series 813/913, of the carrier ZSSK, a. s., took place which provided the fraction of passenger trains in the session Kúty - Skalica in Slovakia. Thanks to this the line was utilised. Every day the armament was provided with one pair of a train set. In December 2013 the cooperation was ended and performances on this line were reduced to minimum (Tomančák, 2012). 
Freight transport was provided only with engine trains of freight transport which utilised the line in case of deviations.

Since the line timetable 2016/2017 the line has been utilised only to a minimum extent, occasionally for actions of railway enthusiasts and for drives organised with Railway Museum of the Slovak Republic

\section{Results and Discussions}

With respect to the analysis of the current state of railway transport on the given line we have focused our research on these three areas:

- utilisation of the line for deviations while reconstructing the $\mathrm{IV}^{\text {th }}$ transit corridor, namely the section Kúty - Kúty, the state border,

- restoration of passenger transport on the given line based on requirements of passengers, arising from a questionnaire research,

- change of a route of freight trains in the direction Kúty - Břeclav - Přerov, and back via the border crossing Holíč nad Moravou - Hodonín.

\section{1. Utilisation of the Line for Deviations}

The line section Kúty - Kúty, the state border, is part of the $\mathrm{IV}^{\text {th }}$ transit corridor and at the same time it is part of the main line of the $7^{\text {th }}$ RFC corridor. Due to these reasons a complex reconstruction of the section for the speed $160 \mathrm{~km} \cdot \mathrm{h}^{-1}$ is planned.

The entire reconstruction project of the section will run simultaneously with the reconstruction of the section Devínska Nová Ves - Malacky. The whole reconstruction will be co-financed with the European Union through CEF, a tool for linking Europe (Železnice Slovenskej republiky, 2018). Figure 2 plots the site of realising the traffic closure works.

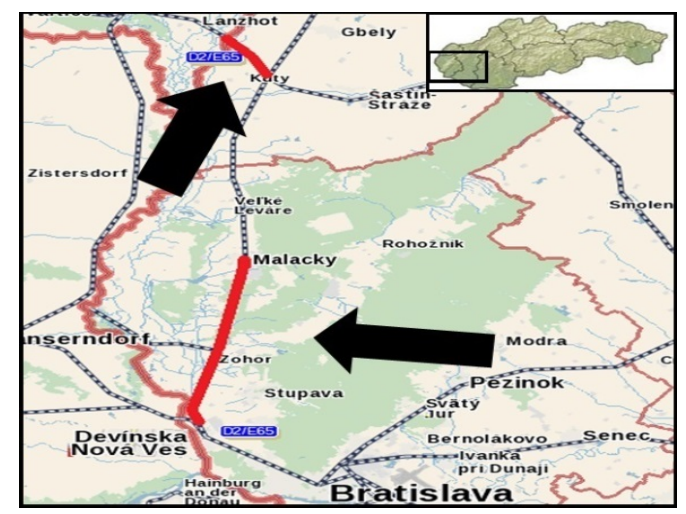

Figure 2. The Site of the Project Realisation

While realising the traffic closure works one of two line tracks will always be free. Since the traffic closure works will run on two sections simultaneously, some measures will be required in both passenger and freight transport (Šulko, 2019). Table 7 describes the traffic closure measures in passenger and freight transport as they are scheduled by the manager of the infrastructure (Šulko, 2019).

Table 7. The Traffic Closure Measures

\begin{tabular}{|l|l|}
\hline $\begin{array}{l}\text { Measures in Passenger } \\
\text { Transport }\end{array}$ & Measures in Freight Transport \\
\hline $\begin{array}{l}\text { Passenger trains will be } \\
\text { cancelled in the section Kúty } \\
\text { - Břeclav and they will be } \\
\text { replaced with replacement } \\
\text { bus transport }\end{array}$ & $\begin{array}{l}\text { Nex and Pn trains in the branch } \\
\text { routed through Trnava and } \\
\text { Jablonica }\end{array}$ \\
\hline $\begin{array}{l}\text { For other train categories } \\
\text { their travelling time will be } \\
\text { extended }\end{array}$ & $\begin{array}{l}\text { Handling trains in the section } \\
\text { Kúty - Kúty, the state border, } \\
\text { do not drive }\end{array}$ \\
\hline
\end{tabular}

After reducing the number of passenger transport trains to 28 trains per day, the limiting section will not be the section Kúty - Kúty, the state border, but the section Sered' - Trnava, where only 24 trains can fit according to the Book of the Throughput of ŽSR. During the traffic closure there would 52 trains in the section Kúty - Kúty, the state border, drive.

To verify the forward performance the methodology of a theoretical forward performance of ŽSR was applied; it is characterised in more details in Chapter 1. It is plotted in Figures 3 and 4.

\begin{tabular}{|c|c|c|c|c|c|c|c|c|c|}
\hline \multirow{2}{*}{\multicolumn{2}{|c|}{ 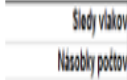 }} & \multicolumn{8}{|c|}{ Dratividi } \\
\hline & & Rosmin & Anoprom & Oaprin & Osmoprin & Anwm & Pnnoris & Ilnopm & Ilnnopry \\
\hline Powisis & $\operatorname{Pos} 1$ & 1 & 1 & , & , & 1 & 1 & , & , \\
\hline Rpatim & 1 & 4 & H & & & 4 & 4 & & \\
\hline Rmpormy & 1 & 18 & (1) & & & 4 & 48 & & \\
\hline anim & 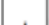 & & & & & & & & \\
\hline & & & & & & & & & \\
\hline & & & & & & & & & \\
\hline Osmpriny & , & & & & & & & & \\
\hline Pnpirin & 1 & 4 & 4 & & & 8 & $\|$ & & \\
\hline Panping & 1 & 4 & 4 & & & $x$ & $\|$ & & \\
\hline theorn & 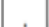 & & & & & & & & \\
\hline IIIIP & ' & & & & & & & & \\
\hline thlowiou & & & & & & & & & \\
\hline Wh noping & , & & & & & & & & \\
\hline
\end{tabular}

Figure 3. Products of the Number of Trains Sequences

Time of occupancy $\left(t_{\text {obs }}\right)$ for individual categories of trains is as follows (Železnice Slovenskej republiky, 2018):

- Ex trains share the same time of occupancy of the interstation section: 7 minutes,

- Pn train of an even direction features the longest time of occupancy of the interstation section: 12 minutes,

- Pn train of an odd direction features the longest time of occupancy of the interstation section: 11 minutes. 


\begin{tabular}{|c|c|c|c|c|c|c|c|c|c|}
\hline \multirow{2}{*}{\multicolumn{2}{|c|}{ Seloy vidor }} & \multicolumn{8}{|c|}{ Dontiy ver } \\
\hline & & Rpoiny & Rneidy & Osping & Osmpisty & Ampirny & Panpiriny & Inpiny & Innpinily \\
\hline Privida & Aid & 7 & 1 & . & . & 6 & 6 & . & . \\
\hline Rpiny & 1 & 14 & $\sharp$ & & & n & 19 & & \\
\hline Rupiny & 1 & 14 & $\Downarrow$ & & & D & 19 & & \\
\hline \multirow{2}{*}{\multicolumn{10}{|c|}{ Oispisy }} \\
\hline & & & & & & & & & \\
\hline \multirow{2}{*}{\multicolumn{10}{|c|}{ Onpism }} \\
\hline & & & & & & & & & \\
\hline Pnpriny & 6 & $n$ & $\Downarrow$ & & & co & 26 & & \\
\hline Panpizaly & 6 & 19 & $\theta$ & & & 25 & 24 & & \\
\hline \multirow{2}{*}{\multicolumn{10}{|c|}{ Unpiny }} \\
\hline & & & & & & & & & \\
\hline In nowim &. & & & & & & & & \\
\hline mintrialy & & & & & & & & & \\
\hline
\end{tabular}

Figure 4. Times of Occupancy with Individual Trains Sequences

The direct time $t_{\text {obs }}$ must be added with the indirect time $t_{\text {obs, }}$ which represents an interval of crossing in RS Kúty and RS Lanžhot. In both RSs the interval will be the same - 1 minute, with respect to matching types of a station interlocking plant (electronic interlockings). The calculation of the practical throughput $\left(\mathrm{n}_{\text {prakt }}\right)$ is to be added with 90 minutes of time of the traffic closures $\left(\mathrm{T}_{\text {výl }}\right)$. Table 8 summarises individual resultant values which are used to make a conclusion (Gašparík \& Šulko, 2016).

Table 8. Resultant Values Required for the Calculation

\begin{tabular}{|l|l|}
\hline Indicator & Value \\
\hline$\sum \mathrm{T}^{\prime}{ }_{\text {obs }}$ & $12,272 \mathrm{~min}$. \\
\hline $\mathrm{T}^{\prime \prime}{ }_{\text {obs }}$ & $13,499.2 \mathrm{~min}$. \\
\hline $\mathrm{T}_{\text {obs }}$ & $259.6 \mathrm{~min}$. \\
\hline $\mathrm{t}_{\text {obs }}$ & $4.99 \mathrm{~min}$. \\
\hline $\mathrm{t}^{\mathrm{sk}}{ }_{\text {medz }}$ & $22.7 \mathrm{~min}$. \\
\hline $\begin{array}{l}\mathrm{t}^{\mathrm{poz̆}}{ }_{\text {medz }} \text { per the regulation } \\
\mathrm{D} 24\end{array}$ & $9.4 \mathrm{~min}$. \\
\hline $\mathrm{t}^{\mathrm{pož}}{ }_{\text {}}{ }_{\text {edz }} \leq \mathrm{t}^{\mathrm{sk}}{ }_{\text {medz }}$ & true \\
\hline $\mathbf{n}_{\text {prakt }}$ & $\mathbf{9 2}$ trains/24 hours \\
\hline
\end{tabular}

When one of two line tracks is excluded, the practical throughput is 92 trains per 24 hours, which is 40 trains more than expected 52 trains per 24 hours. This implies that re-routing under a favourable operation situation will not be required, however, with respect to a stochastic nature of the railway transport industry the necessity to reroute the trains cannot be ruled out. Therefore it would be appropriate to keep the line.

\subsection{Restoration of Passenger Transport on the Basis of a Marketing Survey}

Using a questionnaire survey realised in 2017 - 2019 inhabitants of towns Holíč nad Moravou and Hodonín were asked for their potential interest in restoring the passenger transport. Table 9 represents places, dates and types of surveys which were realised in order to find out a potential of restoring the passenger transport.

Table 9. Realisation of the Survey

\begin{tabular}{|c|c|c|}
\hline Date & Town & Type \\
\hline 2. 2.2017 & $\begin{array}{l}\text { Holíč nad Moravou and } \\
\text { Hodonín }\end{array}$ & \multirow{3}{*}{$\begin{array}{l}\text { Direct address in } \\
\text { a field }\end{array}$} \\
\hline 4. 3. 2017 & Holíč nad Moravou & \\
\hline 11.3. 2017 & Hodonín & \\
\hline $\begin{array}{l}\text { 24. } 6.2018-16 . \\
\text { 4. } 2019\end{array}$ & - & Internet survey \\
\hline
\end{tabular}

Both questionnaires contained several open questions as well as multiple-choice questions. The purpose was to find out and analyse habits of passengers before and after stopping the passenger transport, as well as the option to transit to railway transport in case of restoring the passenger transport. Altogether there were 15 questions and some space for comments in both questionnaires. Moreover, preferred selling channels were investigated. Figure 5 plots results of individual surveys.

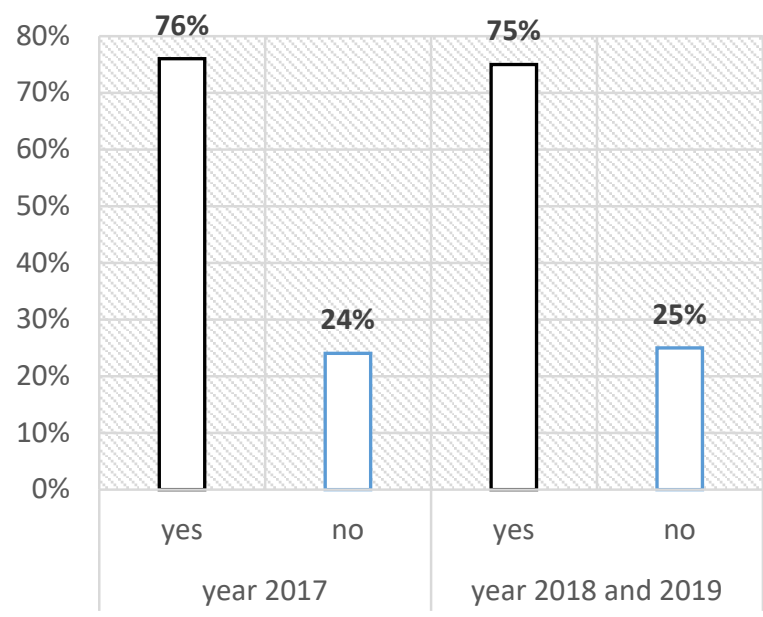

Figure 5. Interest in Restoring the Passenger Transport

The black colour is used to express the respondents' interest in restoring the passenger transport in 2017, and the blue colour is used to express the respondents' interest in restoring the passenger transport in 2018 and 2019. In 2017 the questionnaire was completed by 200 respondents, and in 2018 and 2019 the questionnaire was completed by 40 respondents. This second Internet questionnaire was only a supplementary one, serving to find out a change of the state when compared to 2017. The change in passengers' preferences was negligible.

Based on the results of the questionnaire survey there exists a potential to restore the passenger transport. A potential restoring should meet qualitative and quantitative requirements when creating the timetable. Table 10 lists some selected qualitative and quantitative requirements which are recommended to be met when creating the timetable. They should attract as many passengers as possible. 
Table 10. Requirements of Timetable

\begin{tabular}{|l|l|}
\hline Quantitative Requirements & $\begin{array}{l}\text { Qualitative } \\
\text { Requirements }\end{array}$ \\
\hline Frequency of connections & Speed \\
\hline Number of selling channels & $\begin{array}{l}\text { Accessibility for } \\
\text { the disabled }\end{array}$ \\
\hline \multirow{5}{*}{ Number of seats } & $\begin{array}{l}\text { Easy-to-remember } \\
\text { timing timetable }\end{array}$ \\
\cline { 2 - 2 } & $\begin{array}{l}\text { Continuity of } \\
\text { connections }\end{array}$ \\
\cline { 2 - 2 } & Integration \\
\hline
\end{tabular}

After meeting these basic requirements, the restoration of passenger railway transport would be an interesting alternative to current transport options between the towns Hodonín and Holíč nad Moravou.

\subsection{Re-Routing of Selected Freight Trains}

Selected freight trains driving on the route Kúty Břeclav - Přerov could be re-routed via the border crossing Holíč nad Moravou - Hodonín after meeting the limiting conditions. There are the following limiting conditions:

- a standard of length,

- a standard of weight.

If a train passed without stopping through the section Kúty - Holíč nad Moravou - Hodonín, the standard of length would be irrelevant. With respect to the stochastic character of railway operation it would, however, be risky to ignore the standard of length. In Table 11 there are limiting conditions for the line section Kúty - Holíč nad Moravou and Holíč nad Moravou - Hodonín worked out (Železnice Slovenskej republiky, 2018).

Table 11. The Standard of Length of Limiting Sections

\begin{tabular}{|l|l|}
\hline Section & $\begin{array}{l}\text { Standard of } \\
\text { length }\end{array}$ \\
\hline Kúty - Holíč nad Moravou & $530 \mathrm{~m}$ \\
\hline Holíč nad Moravou - Hodonín & $665 \mathrm{~m}$ \\
\hline
\end{tabular}

The limiting section is not the section Holíc nad Moravou - Hodonín, but the section Kúty - Holíč nad Moravou, a freight train would have to pass through. A limiting RS is Gbely, where the longest track is $530 \mathrm{~m}$ long. The following table contains examples of a standard of weight for selected railway tractive vehicles used most frequently by carriers (Železnice Slovenskej republiky, 2018).

Table 12. The Standard of Weight for Selected Locomotives

\begin{tabular}{|l|l|l|l|}
\hline \multirow{2}{*}{ Section } & $\begin{array}{l}\text { Type of } \\
\text { Resistance }\end{array}$ & $\begin{array}{l}\text { Locomotive } \\
\text { Series }\end{array}$ & Standard \\
\hline \multirow{4}{*}{$\begin{array}{l}\text { Kúty - Holíc and } \\
\text { back }\end{array}$} & $\mathrm{S}$ & \multirow{2}{*}{230,363} & $2,000 \mathrm{t}$ \\
\cline { 2 - 4 } & $\mathrm{T}$ & \multirow{2}{*}{$\mathrm{E} 189$} & $2,200 \mathrm{t}$ \\
\cline { 2 - 3 } & $\mathrm{S}$ & $2,400 \mathrm{t}$ \\
\cline { 2 - 4 } & $\mathrm{T}$ & $2,600 \mathrm{t}$ \\
\hline \multirow{4}{*}{ Hodonín - Holíč } & $\mathrm{S}$ & $2,200 \mathrm{t}$ \\
\cline { 2 - 4 } & $\mathrm{T}$ & 363 & $2,500 \mathrm{t}$ \\
\cline { 2 - 4 } & $\mathrm{S}$ & $3600 \mathrm{t}$ \\
\hline
\end{tabular}

\begin{tabular}{|l|l|l|l|}
\hline & $\mathrm{T}$ & & $2,500 \mathrm{t}$ \\
\cline { 2 - 2 } & $\mathrm{S}$ & \multirow{3}{*}{363.5} & $2,350 \mathrm{t}$ \\
\cline { 2 - 2 } & $\mathrm{T}$ & & $2,800 \mathrm{t}$ \\
\hline \multirow{4}{*}{ Holíč - Hodonín } & $\mathrm{S}$ & \multirow{3}{*}{30} & $1,600 \mathrm{t}$ \\
\cline { 2 - 2 } & $\mathrm{T}$ & \multirow{3}{*}{363} & $1,800 \mathrm{t}$ \\
\cline { 2 - 2 } & $\mathrm{S}$ & $1,600 \mathrm{t}$ \\
\cline { 2 - 2 } & $\mathrm{T}$ & $1,800 \mathrm{t}$ \\
\cline { 2 - 2 } & $\mathrm{S}$ & \multirow{3}{*}{363.5} & $1,700 \mathrm{t}$ \\
\cline { 2 - 2 } & $\mathrm{T}$ & $2,000 \mathrm{t}$ \\
\hline
\end{tabular}

The standard of weight was determined for locomotives, series 230 and 363, always with one active locomotive. These are the most often used types of locomotives by Slovak carriers. Besides, series 210, 740, $742,753,754$ and others are also allowed to transit through the border crossing.

The biggest standard of weight is $2,800 \mathrm{t}$ in the section Hodonín - Holíc chen the locomotive, series 363.5 , is used.

\section{Conclusion}

Regional railway transport is an important part of the national transport system. Despite some regional lines have been showing a low utilisation for longer time it is necessary to study their effectiveness with regard to synergic effects. Our research has shown that the line in question has its potential; moreover it is electrified with an alternate voltage system $25 \mathrm{kV} / 50 \mathrm{~Hz}$, which increases its options of utilisation and at the same time it represents an environmental alternative to road transport.

\section{Acknowledgment}

The paper was supported by the VEGA Agency, Grant No. 1/0019/17 "Evaluation of regional rail transport in the context of regional economic potential with a view to effective use of public resources and social costs of transport", at Faculty of Operations and Economics of Transport and Communication, University of Žilina, Slovakia.

\section{References}

Revitalisation programme of railway companies, Ministry of Transport and Construction, Bratislava, 2011

Contract for the operation of railway infrastructure for years 2017 $-2021$

Dolinayová, A. - Nedeliaková, E. 2015. Controlling in railway transport. 1. edition. Bratislava: Publisher: DOLIS s. r. o., 2015. 147 p. ISBN 978-80-970419-9-1

Gašparík, J. - Šulko, P. 2016. Technology of railway transport: Line transport processes. 1. edition. Žilina: Publisher: EDIS University of Žilina, 2016. 384 p. ISBN 978-80-554$1171-2$

Local convention for controlling the operation and organisation of transport on the railroad on the frontier line and in frontier stations Holíc nad Moravou and Hodonín, regulation of ŽSR/SŽDC, Bratislava/Praha, 2015 http://gvd.cz/cz/data/planky/planky.html https://www.cd.cz/stanice/hodonin/5433845\#home1301 
List of stations of ČD CARGO, regulation of ČD CARGO, a. s., Praha, 2018

Tomančák, L.: From the history of the electrical operation on the line Kúty - Holíč - Hodonín, railway 8, 2000, No. 4 http://www.vlaky.net/servis/trat.asp?id $=6$

Performances on the line Holíč - Holíč, the state border, internal documentation of ŽSR, 2018

https://www.railtrains.sk/modules/AMS/article.php?storyi $\mathrm{d}=902$, https://www.zsr.sk/5106/

A list of the line timetable, line No. 126A, an aid to the line timetable 2018/2019, GR ŽSR, Bratislava 2018

Paperback timetable for the line 129, an aid to the line timetable 2018/2019, GR ŽSR, Bratislava 2018

Dolinayová, A. - Černá, L. - Daniš, J. 2019. Regional Railways Transport-Effectiveness of the Regional Railway Line. Conference on Sustainable Rail Transport (RailNewcastle) Location: Newcastle Univ, Newcastle upon Tyne, ENGLAND. p. 181 - 200

Gašparík, J. - Stopka, O. - Pečený, L. 2015. Quality Evaluation in Regional Passenger Rail Transport. Nase More. Vol. 62, No. 3 (2015), p. 114 - 118

Guihéry, L. Competition in regional passenger rail transport in Germany (Leipzig) and lessons to be drawn for France. Research in Transportation Economics. Vol. 48. p. 298 304.

Masek, J., Kendra, M. Experiences with Providing Transport Services by a Private Carrier in the Regional Railway Transport. Regulated and unregulated competition on rails. Proceedings Paper. Conference on Regulated and Unregulated Competition on Rails, Telc 2013. p. 117 - 129

Skrúcaný, T. - Ponický, J. - Kendra, M. - Gnap, J. 2016. Comparison of railway and road passenger transport in energy consumption and GHG production. $3^{\text {rd }}$ International
Conference on Traffic and Transport Engineering (ICTTE), Belgrade, SERBIA Date: NOV 24-25, 2016. p. $744-749$

Seidenglanz, D., Nigrin, T., Dujka, J. 2015. Regional Railway Transport in Czech, Austrian and German Decentralised and Regionalised Transport Markets. Review of Economic Perspectives. Vol. 15, Issue 4. p. 431 - 450 